\title{
Distribution of Aucuba japonica in two contrasting geobotanical regions of Japan: An analysis of adaptation mode
}

\author{
Md. Sohrab Ali ${ }^{1, *}$ and Kihachiro Kikuzawa ${ }^{2}$ \\ ${ }^{1}$ Department of Environment, E-16, Agargaon, Dhaka - 1207, Bangladesh \\ ${ }^{2}$ Department of Environmental Science, Ishikawa Prefectural University, Suematsu, Nonoichi-cho, Ishikawa 921-8836, Japan
}

\begin{abstract}
Two varieties of Aucuba japonica differ in ways that can be considered adaptive to differing geo-climatic conditions in their respective distribution ranges. Irrespective of growth stage, the mean leaf size of $A$. japonica var. japonica was significantly larger than A. japonica var. borealis. Smaller leaf size and ultimately smaller stature of A. japonica var. borealis are an advantage under the higher snow load and lower temperatures in the forests along the East Sea where the variety grows. Snow load also acted as an important driving force for structural modifications of A. japonica var. borealis from cellular level in leaves to the organization of branch extension growth. Global warming by changing snowfall patterns in Japan may lead to range shifts in the two varieties of $A$. japonica.
\end{abstract}

Key words: adaptation, Aucuba japonica, ecotypic variation, geo-climate, plant growth attributes, snow effects

\section{INTRODUCTION}

The geo-climatic distribution range of the genus $\mathrm{Au}$ cuba extends from the Himalayan region through south China and Taiwan to the easternmost edge of the Japanese archipelago (Hara 1966, Ohi et al. 2003). The genus is genetically differentiated, Chinese species are mostly diploid while those of Japan are tetraploid (Kurosawa 1979, 1981 and Ohi et al. 2003).

Both A. japonica var. japonica and A. japonica var. borealis are tetraploid (Ohi et al. 2003). The morphology of extension unit (EU), leaf, bud of these two closely related varieties changes in accord with local climatic conditions (Kume and Ino 1993, Kume and Ino 2000, Ohi et al. 2003). A. japonica var. japonica prefers the lower snowfall or snow-free areas of the Pacific seaside while A. japonica var. borealis is abundant in the heavy snowfall areas of the Japan seaside where plants remain covered by snow for more than four months (Kume and Ino 2000).
Snow cover may act as a driving force for distribution of varieties of A. japonica (Kume and Ino 2001). The growth of A. japonica var. borealis could be affected adversely by three factors. First, mechanical stress due to snow load may require investment of resources in building stronger branches. A trade-off between plant growth and such mechanical defense is expected (Kume and Ino 1993). Second, low temperature that affects leaf photosynthesis might lead to leaves with thicker epidermis and thicker mesophyll tissue to serve as a heat reservoir (Terashima et al. 2001). Consequent reductions in photosynthesis could lead to further resource constraint and ultimately affect plant growth. Third, a shorter growth period leads to reduced growth and smaller plant size (Kume and Ino 1993). The objective of this study is to assess whether or not there is ecotypic differentiation between these two varieties of A. japonica that reflects adaptation to the con-

\section{Open Access http://dx.doi.org/10.5141/ecoenv.2013.173}

This is an Open Access article distributed under the terms of the Creative Commons Attribution Non-Commercial License (http://creativecommons. org/licenses/by-nc/3.0/) which permits unrestricted non-commercial use distribution, and reproduction in any medium, provided the original work is properly cited.
Received 06 April 2013, Accepted 07 August 2013

*Corresponding Author

E-mail: md.sohrab_ali@yahoo.com; sohrab@doe-bd.org Tel: +880-2-8181777 
trasting snowfall regimes.

In A. japonica, any adaptive differentiation in response to their differing snowfall regimes is likely to play out in variation in EU, leaf size and in the nature of anisophylly, a type of developmental plasticity in leaf size in response to environmental signals (Goebel 1900, Yano and Terashima 2004). Both varieties of $A$. japonica are anisophyllous: a characteristic that is important for reducing self-shading and for the establishment of plants in light deficient habitats (Goebel 1900, Dangler and Sánchez-Burgos 1988). A. japonica var. japonica expresses place-dependent anisophylly on the shoot system due to mechanical stress in the developing bud (Ali and Kikuzawa 2005a). We expect that A. japonica var. borealis should express a lesser degree of anisophylly because of its lower or arrested growth of leaf primordia due to a longer period of snow cover. This would reduce the differential growth of leaf primordia in the bud (Ali and Kikuzawa 2005a) and lead to smaller plant stature and leaf size could be advantageous in a high snowfall region.

As snowfall regimes respond to global warming, the consequences for the two varieties of A. japonica will depend whether any variation in the degree of anisophylly is genetically fixed or not. If the degree of anisophylly is a genetically fixed adaptation then the competitive ability of A. japonica var. borealis could be reduced as snowfall diminishes. On the other hand, if anisophylly is more a plastic response to environmental stress (Ali and Kikuzawa 2005) then under a "no snow cover" scenario (Kume and Ino 1993) A. japonica var. borealis might grow taller with larger leaves. Similar logic applies to $A$. japonica var. japonica, so that shifts in snowfall regime under global warming could well alter the ranges and competitive interactions between the two varieties. To explore these possibilities in this paper, we 1) compared developmental plasticity in the leaves of the two varieties of $A$. japonica and 2) analyzed growth attributes associated with differences in plant stature.

\section{MATERIALS AND METHODS}

A. japonica is an evergreen, understory shrub widely distributed from warm to cool temperate forests in Japan (Andersen et al. 1991, Kume and Ino 2001). A. japonica is dioecious; reproduction begins in 4-year old plants but may be delayed until 15 years (Kume and Ino 2000). Phyllotaxis is almost always decussate from vegetative to reproductive appendages (Hara 1980). We studied two varieties of A. japonica (Garryaceae): var. japonica and var. borealis. From now on, names of the varieties, $A$. japonica var. japonica and A. japonica var. borealis, would be abbreviated to var. japonica and var. borealis, respectively. Variety of var. borealis has hairs appressed on the petiole and a creeping stem while var. japonica has hairless petiole and a more erect stem (Kume and Ino 1993).The two varieties grow in contrasting geobotanical regions of Japan. Variety of var. japonica is distributed in parts of eastern Japan that are snow-free or have relatively low snowfall while var. borealis is abundant in western regions with heavy snowfall along the East Sea where plants typically remain snow-covered for more than four months (Kume and Ino 2000). The leaf replacement pattern of $A$. japonica is in accordance with seasonal changes in the temperature regimes. For var. borealis new leaves start to expand in late March to April and gradually expand until late August (Kawano and Takasu 2004) while for var. japonica leaves expand from February to late July (Ali and Kikuzawa 2005a).

We sampled var. japonica from the Botanical Garden of Kyoto University situated at $35^{\circ} 02^{\prime} \mathrm{N}, 135^{\circ} 47^{\prime} \mathrm{E}$, and 60 $\mathrm{m}$ above sea level (a.s.l.). Annual mean temperature was $16.1^{\circ} \mathrm{C}$ with a mean annual precipitation of $1,539 \mathrm{~mm}$. We sampled var. borealis in the Noto Peninsula region of Ishikawa Prefecture (Fig. 1) at altitudes from 10 to $468 \mathrm{~m}$ a.s.l. Annual mean temperature is $13.28^{\circ} \mathrm{C}$ and the mean annual precipitation is $2,679 \mathrm{~mm}$ with annual mean snowfall of $6.04 \mathrm{~m}$ and maximum snow depth of 1.12 $\mathrm{m}$. Samples from locations in Ishikawa prefecture were pooled to represent the geo-climatic regime associated with the Sea of Japan. All the locations are situated within the geographic range of $36^{\circ} 26^{\prime} 13.7^{\prime \prime} \mathrm{N}$ to $37^{\circ} 29^{\prime} 45.6^{\prime \prime} \mathrm{N}$ and $136^{\circ} 38^{\prime} 04.6^{\prime \prime}$ E to $137^{\circ} 20^{\prime} 42.6^{\prime \prime} \mathrm{E}$.

\section{Description of Buds}

The types and structure of buds play a key role in initiating morphological changes such as anisophylly and EU dimorphism that determine plant form. Aucuba plants produce both terminal vegetative and terminal reproductive buds. The terminal buds commonly have two pairs of bud scales (Hara 1980) and each scale contains a small axillary bud primordium in its axil. The axillary buds of the terminal reproductive bud develop into new anisophyllous EUs. So, a terminal reproductive bud has the potential to extend four EUs on the supporting EU apex. The axillary buds of the terminal vegetative bud do not develop into EUs. Only the apical meristem of the terminal vegetative bud develops into a single new isophyllous EU (Hara 1980, Ali and Kikuzawa 2005a). 


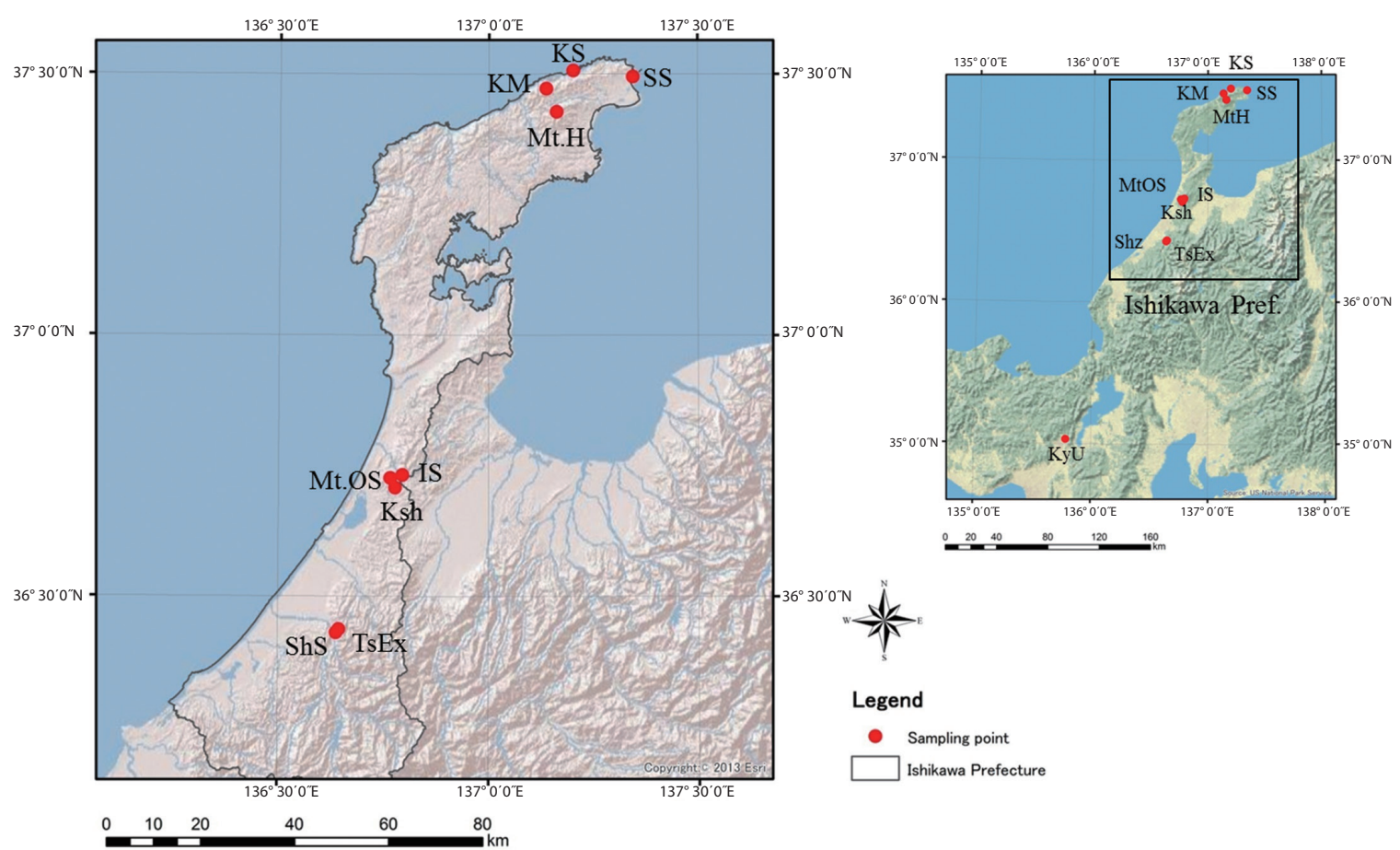

Fig. 1. Sampling locations of Aucuba japonica var. borealis on the Noto Peninsula. The locations are: SS, Suzu Shrine; KS, Kasuga Shrine; KM, Kakuma-mati; Mt.H, Mount Horyu; Mt.OS, Mount Oyama Shrine; Ksh, Kaizaki Shrine; ShS, Shirayama Shrine; TsEx, Tsurugi experimental station of Ishikawa Prefectural University; KyU, Kyoto University Botanical Garden.

To describe features of anisophylly and to find a causal relationship, we used various methods to measure the different but inter-related growth attributes given below.

\section{Measurement of bud size}

We measured dimensions of randomly selected terminal reproductive buds on mature plants of var. japonica around the end of 2003 at the Botanical Garden of Kyoto University and of var. borealis at the end of growing season in 2010 at different locations in Ishikawa Prefecture (Fig. 1). Generally buds were rather elliptical in cross sectional view, elongated in the direction of the first pair of bud scales while suppressed in the direction of the second pair (Ali and Kikuzawa 2005a). Thus, bud diameter (a, b; $>$ b) was measured in two direction perpendicular to each other and then averaged. Assuming a conical shape, we estimated bud size (volume) by the equation, $S=\frac{1}{3} \pi \mathrm{r}^{2} \mathrm{~h}$, where $\mathrm{r}=$ radius [estimated as $\mathrm{r}=\mathrm{D} / 2$, while $\mathrm{D}=(\mathrm{a}+\mathrm{b})$ / 2] and $h=$ bud length, respectively.

\section{Measurement of individual leaf area of mature leaves}

For both A. japonica varieties, we measured leaf laminar length and the maximum width of fully expanded leaves to the nearest $\mathrm{mm}$ at each nodal position of randomly selected EUs throughout the crown of both adult and juvenile plants. For var. borealis, we also measured fully expanded mature leaves $(N=127)$ on current sprouts on old stems where the entire plant was cut at ground level. We estimated individual leaf $(N=150)$ area by the equation, $\mathrm{Y}=0.682 \times \mathrm{X}(\mathrm{r}=0.999)$ where $\mathrm{X}=$ lamina length $\times$ width (Ali and Kikuzawa 2005a). The leaf area $(N=150)$ of var. borealis was measured using a leaf area meter (LI3100; LI-COR, Lincoln, NE, USA) which was strongly correlated with this estimate $(r=0.999, P<0.01)$.

\section{Measurement of the degree of anisophylly}

A. japonica expresses anisophylly on every alternate nodal position on the EU. We estimated the degree of anisophylly as the ratio of leaf area of two leaves opposite to each other on a node. For the anisophyllous nodes (e.g., $\mathrm{N}_{2}, \mathrm{~N}_{4}$ if there were four nodes on an extension unit), we used the ratio of outer (away from the inflorescence) to inner (on the side of the inflorescence) leaf area. For isophyllous nodes (e.g., $\mathrm{N}_{1}$ and $\mathrm{N}_{3}$; where leaves grow tan- 
gential to the inflorescence), we selected the numerator and the denominator of the ratio for each nodal position randomly because of difficulty in distinguishing the inner or outer leaf.

\section{Measurement of total leaf area per node}

To compare leaf area and to display at each nodal position of an EU, we calculated total leaf area, i.e., the sum of area of the two leaves at a node.

\section{Determination of specific leaf area (SLA)}

To compare SLA between the two varieties, we sampled eighty, current season EUs (with two to three pairs of leaves each) from around the crown of mature plants. We measured laminar dimensions of all the leaves. Sampled leaves $(N=395)$ were oven dried to constant weight to estimate specific leaf area as the leaf area per unit dry mass $\left(\mathrm{cm}^{2} / \mathrm{g}\right)$.

\section{Paraffin embedding of sample, sectioning and staining}

For anatomical comparison, we sampled ten pairs of leaves at the second nodal position (acropetally) for each variety and preserved them immediately in $4 \%$ FormalinAcetic-Alcohol (FAA). Samples we collected from Tsurugi experimental station in Ishikawa Prefecture.

We followed standard methods (Takasoh et al. 1997) for leaf anatomy. Sections of $10 \mu \mathrm{m}$ thickness were prepared using a rotary microtome. For leaves, a small piece was cut from between the third and fourth lateral vein and inbetween the mid rib and the margin of lamina for sectioning.

\section{Measurement of EU length and diameter on mature plants}

EU was defined as the lateral axis that has grown out in a year from the axillary bud enveloped by the bud scales of the terminal bud. To compare EU length between two varieties, we measured length of all EUs on randomly selected clumps. To obtain a representative EU length with minimum temporal effect, we defined the entire extension growth of a selected EU over last five years as a clump (Ali and Kikuzawa 2012). Clump selection was random and irrespective of branch order. We measured the diameter of current EUs by a caliper around the middle of the EU.
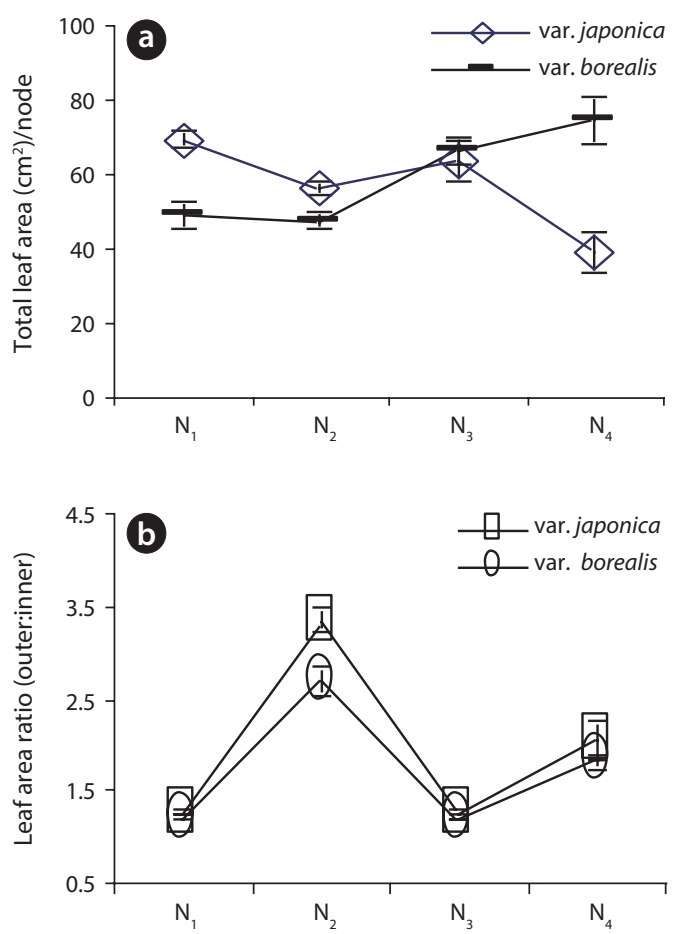

Fig. 2. Foliage leaf display pattern on the shoot system of Aucuba japonica. (a) Comparison of sum of two leaves area displayed on each nodal position. $\mathrm{N}_{1}$ to $\mathrm{N}_{4}$ indicate nodal positions on an EU acropetally. (b) Comparison of anisophylly along the shoot system.

\section{Determination of stem wood density}

For determination of stem wood density we collected current-year EUs. Immediately after harvesting, we separated stems and leaves. We measured stem length and diameter. Diameter was measured at the middle of the EU. Samples were oven dried at $80^{\circ} \mathrm{C}$ to constant weight.

To estimate EU wood density $\left(\mathrm{g} / \mathrm{cm}^{3}\right)$, assuming cylindrical shape, we estimated EU wood volume $\left(\mathrm{cm}^{3}\right)$ as $\mathrm{V}_{\mathrm{S}}=$ $\mu r^{2} \mathrm{~h}$, where $\mathrm{r}=\mathrm{D} / 2$ (D is stem diameter in $\mathrm{cm}$ ) and $\mathrm{h}=\mathrm{EU}$ length $(\mathrm{cm})$.

\section{Measurement of mature plant height}

We measured adult male plant height along the stem from ground level to the growing tip $(N=98)$ for individuals from forest edge to interior. We selected individual plants (Isobe and Kikuchi 1989) by visual observation; the sampled plants of var. borealis ranged from 9 to 27 years old and var. japonica from 5 to 26 years old as estimated by the total number of branching points; branching occurs only once in a year in A. japonica (Kume and Ino 2000). 
a

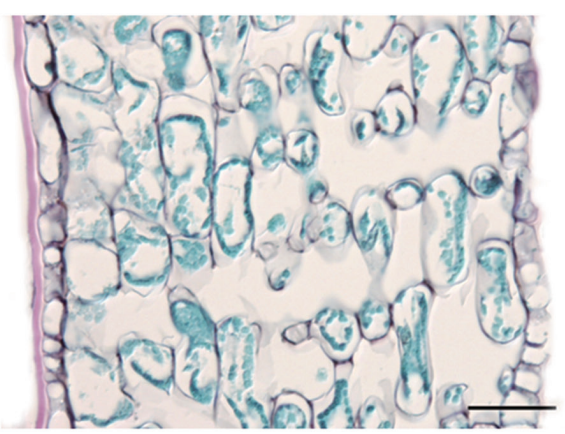

var. borealis (outer leaf)
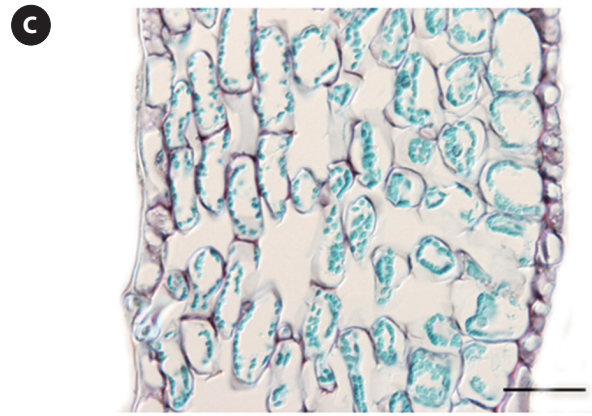

var. borealis (inner leaf)

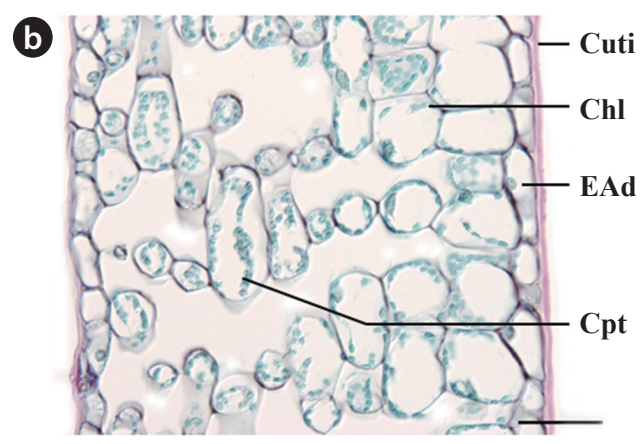

var. japonica (outer leaf)

d

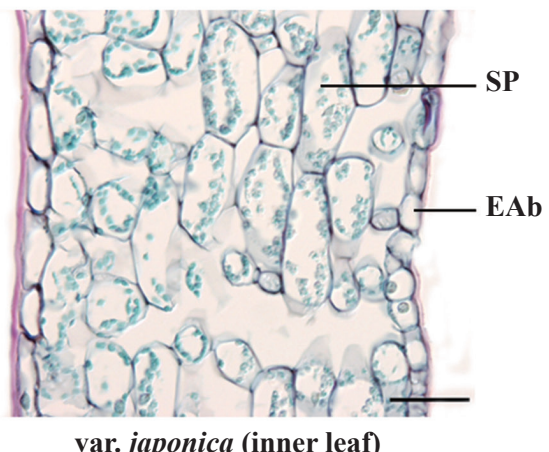

Fig. 3. Anatomy of fully expanded anisophyllous leaves of the two varieties of Aucuba japonica at the $\mathrm{N}_{2}$ position. (a) Cross-section of outer leaf of var. borealis. (b) Cross-section of outer leaf of var. japonica. (c) Cross-section of inner leaf of var. borealis. (d) Cross-section inner leaf of var. japonica. Scale bar = $50 \mu \mathrm{m}$. Different parts of the cross-sections are as follows: Cuti, Cuticle layer; Chl, Chlorenchyma cell; EAd, Epidermal cell (Adaxial side); Cpt, Chloroplast; SP, Spongy Parenchyma cell; EAb, Epidermal cell (Abaxial side).

\section{Statistical analyses}

For statistical analyses, One-way ANOVA in case of homogenous data set, Two-way ANOVA to test interaction effect, and Mann-Whitney U test for heterogeneous data set were used. To obtain graphs, SPSS ver. 8.5 (SPSS, Chicago, IL, USA) and Excel were used.

\section{RESULTS}

Total leaf area per node of var. japonica decreased acropetally while var. borealis showed an increasing trend in total leaf area along the EU. In Fig. 2, the sum of leaf area at $\mathrm{N}_{1}$ and $\mathrm{N}_{2}$ nodal positions was 1.5 times higher for var. japonica than var. borealis. At the $\mathrm{N}_{3}$ nodal position, total leaf area per node between two varieties was closer to each other but at the $\mathrm{N}_{4}$ node, the sum of leaf area per node $\left(\mathrm{cm}^{2} /\right.$ node) was significantly higher $(P<0.001$, Oneway ANOVA) in var. borealis than var. japonica (Fig. 2a). Both varieties expressed moderate anisophylly on alternate nodal positions along the $\mathrm{EU}$, but at the $\mathrm{N}_{2}$ position of var. japonica had greater $(P<0.001$, Mann Whitney $\mathrm{U}$ test) anisophylly than var. borealis. The degree of anisophylly at $\mathrm{N}_{4}$ did not differ between the two varieties $(P>$ 0.05, Mann Whitney U test) (Fig. 2b).

A. japonica var. japonica produced 3.5 times larger terminal reproductive buds than var. borealis (Table 1). The terminal reproductive buds of $A$. japonica initiate dimorphisms that are amplified following bud break. Irrespective of plant growth stages, the mean leaf size of var. japonica was 1.2 times larger than that of var. borealis (Table 2). On broken or damaged stems of var. borealis, leaves on sprouts grow from the terminal vegetative bud. Mean

Table 1. Comparison of terminal reproductive bud size $\left(\mathrm{cm}^{3}\right)$ between varieties of Aucuba japonica

\begin{tabular}{ccc}
\hline Varieties & $\begin{array}{c}\text { Bud size } \\
\left(\text { Mean } \pm \mathrm{SE}^{*}\right)\end{array}$ & $\begin{array}{c}\text { Level of } \\
\text { significance }\end{array}$ \\
\hline $\begin{array}{c}\text { A. japonica } \text { var. } \\
\text { japonica }\end{array}$ & $0.710 \pm 0.040$ & \\
$\begin{array}{c}\text { A. japonica } \text { var. } \\
\text { borealis }\end{array}$ & $0.020 \pm 0.001$ & $\begin{array}{c}P<0.001, \\
\text { One-way ANOVA }\end{array}$ \\
\hline
\end{tabular}

"SE is standard error. 


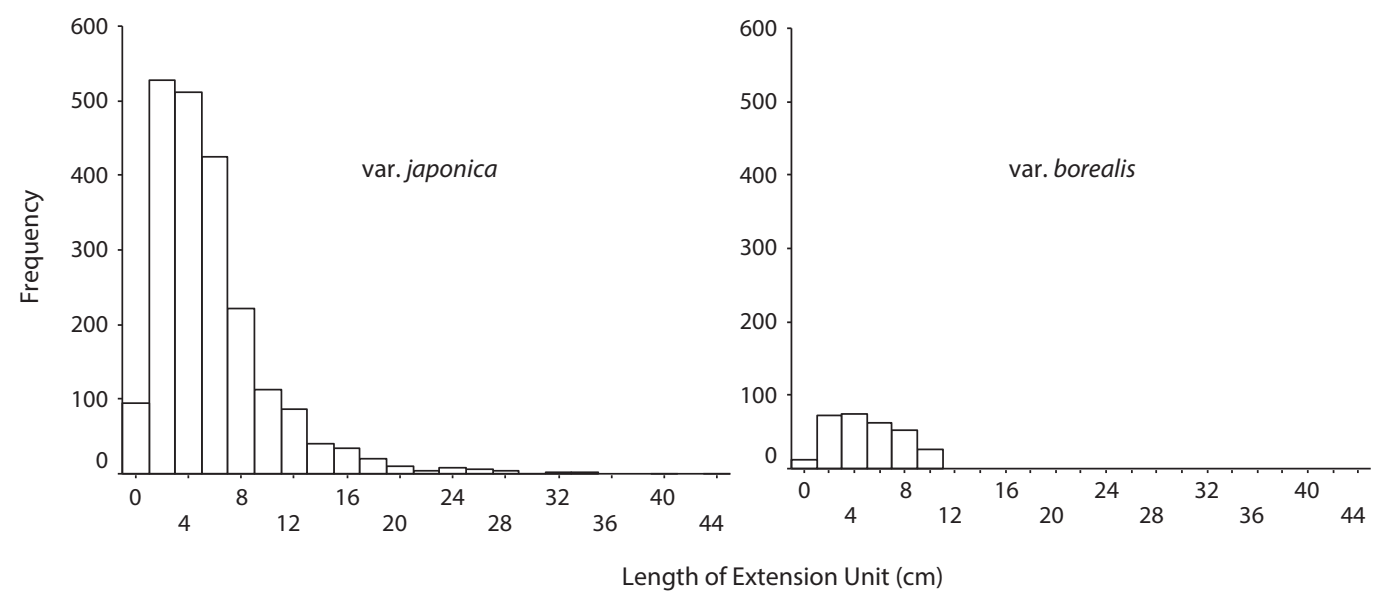

Fig. 4. Comparison of EU length between the two varieties of Aucuba japonica. To minimize any temporal effect on EU length we measured EUs only on clumps in mature crowns. $N=500$ for var. japonica and $N=300$ for var. borealis respectively.

leaf size on sprouts of var. borealis was $79.29 \pm 3.54 \mathrm{~cm}^{2}$. SLA of var. borealis was 1.06 times greater $(P<0.05$, Mann Whitney U test) than var. japonica (Table 3).

Table 2. Comparison of leaf size $\left(\mathrm{cm}^{2}\right)$ between varieties of Aucuba japonica in context of growth stages (juvenile and adult)

\begin{tabular}{cccc}
\hline Varieties & \multicolumn{2}{c}{$\begin{array}{c}\text { Leaf size } \\
(\text { Mean } \pm \text { SE) }\end{array}$} & $\begin{array}{c}\text { Level of } \\
\text { significance }\end{array}$ \\
\cline { 2 - 3 } & Juvenile & Adult & \\
\hline $\begin{array}{c}\text { A. japonica } \text { var. } \\
\text { japonica }\end{array}$ & $54.74 \pm 2.31$ & $32.16 \pm 0.29$ & \\
$\begin{array}{c}\text { A. japonica } \text { var. } \\
\text { borealis }\end{array}$ & $49.95 \pm 2.07$ & $25.71 \pm 0.73$ & $\begin{array}{c}P<0.001, \\
\text { Two-way ANOVA }\end{array}$ \\
\hline
\end{tabular}

Table 3. Comparison of Specific Leaf Area (SLA) $\left(\mathrm{cm}^{2} / \mathrm{g}\right)$ between varieties of Aucuba japonica

\begin{tabular}{ccc}
\hline Varieties & $\begin{array}{c}\text { SLA } \\
(\text { Mean } \pm \text { SE) }\end{array}$ & $\begin{array}{c}\text { Level of } \\
\text { significance }\end{array}$ \\
\hline $\begin{array}{c}\text { A. japonica } \text { var. } \\
\text { japonica }\end{array}$ & $139.44 \pm 4.22$ & $P<0.05$, \\
$\begin{array}{c}\text { A. japonica } \text { var. } \\
\text { borealis }\end{array}$ & $147.00 \pm 6.66$ & Mann Whitney U test \\
\hline
\end{tabular}

Table 4. Comparison of Extension Unit (EU) length (cm) between two varieties of Aucuba japonica

\begin{tabular}{ccc}
\hline Varieties & $\begin{array}{c}\text { EU length } \\
(\text { Mean } \pm \text { SE) }\end{array}$ & $\begin{array}{c}\text { Level of } \\
\text { significance }\end{array}$ \\
\hline $\begin{array}{c}\text { A. japonica } \text { var. } \\
\text { japonica }\end{array}$ & $5.68 \pm 0.10$ & $\begin{array}{c}P<0.001, \\
\text { A. japonica } \text { var. } \\
\text { borealis }\end{array}$ \\
\hline
\end{tabular}

The histology of fully expanded anisophyllous leaves of both varieties did not differ in terms of cell shape and size, cell wall thickness or the number of cell layers (Fig. 3 ). Leaves had 10 to 12 layers of foliar cells including the epidermal layers. The single layered epidermis was covered with a thick cuticle layer mainly on the adaxial side; stomata were confined to the abaxial epidermis. Chlorenchyma was composed of two layers of large, rectangular cells (in surface view); chloroplasts were mainly concentrated adaxially. Spongy parenchyma was composed of round, elongated cells suppressed at both ends.

A. japonica var. japonica produced EU lengths of wider range compare to var. borealis (Fig. 4). The mean EU length of var. japonica was $5.68 \pm 0.10 \mathrm{~cm}$ while that of var. borealis was $4.72 \pm 0.15 \mathrm{~cm}$ (Table 4 ). Mean wood density of the current-year EU did not differ between the two varieties (Table 5).

The mean individual plant height of var. japonica was $2.32 \pm 0.16 \mathrm{~m}$, and it was greater than $1.27 \pm 0.12 \mathrm{~m}$ of var. borealis $(P<0.001$, One-way ANOVA) (Table 6$)$. This indicates that at a comparable age, each growth height in var. japonica exceeds that of var. borealis (Fig. 5). Individual plants of var. japonica generally attained greater height growth than var. borealis, but some individuals of var. borealis about $5 \mathrm{~m}$ tall were found in a gap at the Tsurugi Experimental Forest.

\section{DISCUSSION}

The terminal reproductive bud of $A$. japonica grows in response to both its size and local environmental conditions; space available on the apical dome (Wardlaw 1952) 


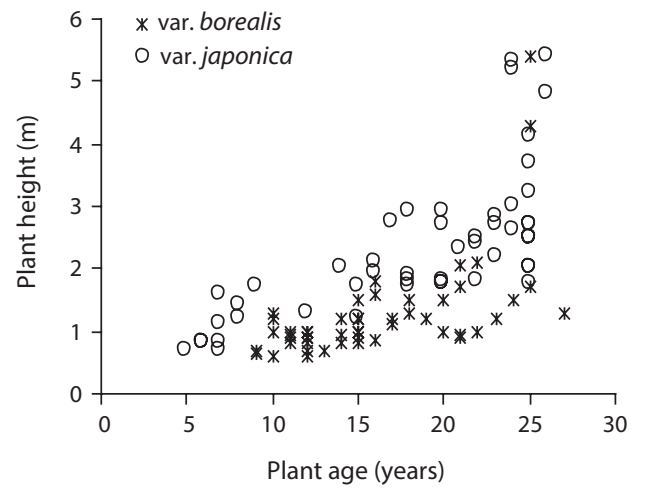

Fig. 5. Comparison of plant height between two varieties of Aucuba japonca.

plays a pivotal role in modulating organ shape and size. The larger the apical dome, the greater the space available for growing organs. A larger apical dome contributed to development of the larger leaves of var. japonica. In turn, a smaller bud size and consequent congestion on the apical dome of var. borealis contributed to its smaller leaf size (Wardlaw 1952, Ali and Kikuzawa 2005a). Further, the arrested or extremely slow growth due to snow cover led to smaller leaves in var. borealis (Kume and Ino 1993, Ali and Kikuzawa 2005a). Thus, all of space congestion in buds, arrested or slow growth, and a shorter growth period associated with snow cover contributed to smaller leaf size in var. borealis compared to var. japonica. The thinner

Table 5. Comparison of wood density $\left(\mathrm{g} / \mathrm{cm}^{3}\right)$ of current EUs between varieties of Aucuba japonica

\begin{tabular}{ccc}
\hline Varieties & $\begin{array}{c}\text { Wood density } \\
(\text { Mean } \pm \text { SE) }\end{array}$ & $\begin{array}{c}\text { Level of } \\
\text { significance }\end{array}$ \\
\hline $\begin{array}{c}\text { A. japonica } \text { var. } \\
\text { japonica }\end{array}$ & $0.39 \pm 0.03$ & $\mathrm{NS}^{*}$ \\
$\begin{array}{c}\text { A. japonica } \text { var. } \\
\text { borealis }\end{array}$ & $0.37 \pm 0.02$ & \\
\hline
\end{tabular}

"NS means that there is no significance in difference between the two varieties.

Table 6. Comparison of plant height $(\mathrm{m})$ between varieties of Aucuba japonica

\begin{tabular}{ccc}
\hline Varieties & $\begin{array}{c}\text { Plant height } \\
(\mathrm{Mean} \pm \mathrm{SE})\end{array}$ & $\begin{array}{c}\text { Level of } \\
\text { significance }\end{array}$ \\
\hline $\begin{array}{c}\text { A. japonica } \text { var. } \\
\text { japonica }\end{array}$ & $2.32 \pm 0.16$ & \\
$\begin{array}{c}\text { A. japonica } \text { var. } \\
\text { borealis }\end{array}$ & $1.27 \pm 0.12$ & $\begin{array}{c}P<0.001, \\
\text { One-way ANOVA }\end{array}$ \\
\hline
\end{tabular}

leaves of var. borealis may be explained by a shading effect (Kume and Ino 1993) although the mechanism is unclear.

Differences in temperature regime in the regions could have significant impact on the production ecology (Yano and Terashima 2004). Differential timing and duration of the leaf expansion period leads to different leaf size even on a single EU (Kawano and Takasu 2004, Ali and Kikuzawa 2005a). In the absence of snow, low temperature alone is likely to reduce leaf growth, particularly in the early leaves (at $\mathrm{N}_{1}$ and $\mathrm{N}_{2}$ nodes) on an EU of var. borealis; later developing leaves enjoy better environmental conditions as the season progresses (Terashima et al. 2001, Kume 2005). Later in the season, warming followed by melting of snow cover acts as drift of growth for later leaves (Yamada et al. 2000). Moreover, the supply of photosynthate from early leaves further enhances growth of later leaves, which thus attain even large size (Osada and Takeda 2003). Contrarily, a longer growth period in a snow-free environment enables early leaves of var. japonica to attain larger size while early termination of growth leads to later leaves being smaller on an EU (Kume and Ino 1993, Ali and Kikuzawa 2005a). Both differences in temperature during leaf development (Bertin 2008) and the position of leaves can lead to contrasting patterns of leaf display along the EU. So, leaf growth plastically responded to environmental opportunity. During growth, leaves also can respond adaptively to environmental signals affecting leaf size (Yano and Terashima 2004). Smaller leaves help reduce mechanical stress by snow loading. Indifferent wood density of two varieties let them to make dimensional adjustment of EU to attain required mechanical strength. Accordingly, to cope with snow load, var. borealis has to develop shorter EU. Cumulative growth of shorter EUs led to smaller stature of var. borealis.

The similar pattern of anisophylly in both varieties may be explained by their common decussate phyllotaxis (Ohi et al. 2003), but variation in the degree of anisophylly can be affected by differences in their environmental regimes. Disproportionate mechanical stress on inner and outer leaf primordia in the bud leads to differential growth initiating anisophylly in A. japonica (Ali and Kikuzawa 2005a), while the rate of differential growth determines the degree of anisophylly. The arrested or slowed growth of leaf primordia in the bud under snow cover thus leads to a lesser degree of anisophylly in var. borealis by reducing the differential growth of leaf primordia (Ali and Kikuzawa 2005a). The subsequent disappearance of snow cover and bud break releases all primordia from mechanical stress and paves the way to free growth. Freeing from mechanical stress later in the season leads to a decrease 
in the degree of anisophylly toward the tip of the EU of var. borealis (Ali and Kikuzawa 2005a).

The difference in plant stature of these varieties can be explained by the difference in their opportunities for photosynthetic activity in winter (Kume 2005). Stored reserves in the above and belowground parts of plant (Chapin et al. 1990) along with a warmer snow-free environment (Kimbal et al. 2006) leads to larger leaf production on sprouts of var. borealis. Acropetal increase in leaf size on an EU and larger leaves on sprouts indicated that var. borealis did not lose growth potential permanently and could produce even larger leaves in favorable environmental conditions. This is equally applicable to whole plant growth in var. borealis (Kume 2005). On the other hand, ex situ growth of var. japonica (Kume and Ino 1993) suggests that it has the ability to survive in areas where it does not grow normally. Global warming could enhance invasion of new areas by both varieties (Bertin 2008). Under a "no snow cover plus low irradiance" scenario (Kume and Ino 2000), greater self-shading owing to larger leaves would reduce plant performance. In that case, anisophylly could act as a rescue mechanism exposing more leaf area for photosynthesis by reducing self-shading (Ali and Kikuzawa 2005b) and allowing greater photosynthetic gains. Thus it is possible that global warming could improve performance of var. borealis and intra-specific biodiversity may remain unaffected (Parmesan 2006, Bertin 2008).

\section{CONCLUSION}

Anisophylly in A. japonica is a genetically controlled and environment-responsive characteristic. A common but environmentally differentiated growth response to regional climatic conditions leads to different plant stature within Japan. Snow load has a significant impact on plant stature rather than architecture of A. japonica.

While analyzing plant growth attributes it surfaced up that A. japonica var. borealis did not lose its growth potential permanently; it can grow bigger if environment favors. Owing to greater plasticity of growth, A. japonica has wider adaptability from snowy to snow free environment and global warming would help varieties of $A$. japonica to spread over new areas and thus, varietal diversity would be conserved.

\section{ACKNOWLEDGEMENTS}

We are thankful to the Botanical Garden Authority of
Kyoto University and Tsurugi Experimental Forest for permission to conduct experimental work there. We are highly indebted to Masaki Takagi, member of Botanical society of Ishikawa, for identification of sampling plants at different locations on Noto peninsula, to Eiji Tanaka for allowing us to carry out anatomical work in his laboratory and to Seiji Yanai for providing a GIS map of Noto peninsula. We especially thank Dr. Kohei Koyama of Laboratory of Plant Ecology, Ishikawa Prefectural University for his support during the experimental work. Finally we express our deep gratitude to Martin J. Lechowicz, professor of McGill University and Director of Gault Nature Reserve, Canada, for his critical review of the manuscript and providing us with constructive suggestions.

\section{LITERATURE CITED}

Ali MS, Kikuzawa K. 2005a. Anisophylly in Aucuba japonica (Cornaceae): An outcome of spatial crowding in the bud. Can J Bot 83: 143-154.

Ali MS, Kikuzawa K. 2005b. Shoot morphology of Aucuba japonica incurred by anisophylly: ecological implications. J Plant Res 118: 329-338.

Ali MS, Kikuzawa K. 2012. Responses of different phytoelements to habitat light level and their dynamic convergence towards crown development of Aucuba japonica Thunb. var. japonica. J Ecol Field Biol 35: 177-188.

Andersen PC, Knox GW, Norcini JG. 1991. Light intensity influences growth and leaf physiology of Aucuba japonica 'Variegata'. Hortscience 26: 1485-1488.

Bertin RI. 2008. Plant phenology and distribution in relation to recent climate change. J Torrey Bot Soc 135: 126-146.

Chapin FS, Schulze ED, Mooney HA. 1990. The ecology and economics of storage in plants. Annu Rev Ecol Syst 21: 423-447.

Dengler NG, Sánchez-Burgos AA. 1988. Effect of light level on the expression of anisophylly in Paradrymonia ciliosa (Gesneraceae). Bot Gaz 149: 158-165.

Goebel K. 1900. Organography of Plants, especially of the Archegoniata and Spermaphyta. Clarendon Press, Oxford.

Hara H. 1966. Taxonomic comparion between corresponding taxa of Spermatophyta in Eastern Himalaya and Japan. In: The Flora of Eastern Himalaya (Hara H, ed). University of Tokyo, Tokyo, pp 627-657.

Hara N. 1980. Shoot development of Aucuba japonica I. Morphological study. Bot Mag Tokyo 93: 101-116.

Isobe H, Kikuchi T. 1989. Differences in shoot form and age of Aucuba japonica Thunb. corresponding to the microlandforms on a hill slope. Ecol Rev 21: 277-281. 
Kawano S, Takasu H. 2004. Life history characteristics of $A u$ cuba japonica Thunb. var. borealis Miyabe et Kudo (Cornaceae). In: Life History Monographs of Japanese Plants Vol. II: No. 2, Spring Plants (Kakiano S, ed). HokkaidoDaigaku Tosho Kankokai, Sapporo, pp 48.

Kimball JS, McDonald KC, Zhao M. 2006. Spring thaw and its effect on terrestrial vegetation productivity in the western arctic observed from satellite microwave and optical remote sensing. Earth interact 10: 1-22.

Kume A. 2005. Trees Adaptive to snow - Aucuba japonica var. borealis and Camellia japonica var. decumbens. In: Snow and Plants. The Botanical Society of Japan, Toyama, pp 17-20. (In Japanese)

Kume A, Ino Y. 1993. Comparison of ecophysiological responses to heavy snow in two varieties of Aucuba japonica with different areas of distribution. Ecol Res 8: 111-121.

Kume A, Ino Y. 2000. Differences in shoot size and allometry between two evergreen broad-leaved shrubs, Aucuba japonica varieties in two contrasting snowfall habitats. J Plant Res 113: 353-363.

Kume A, Ino Y. 2001. Why is Aucuba japonica smaller in heavy snowfall areas? A growth simulation of evergreen broad-leaved shrubs based on shoot allometry, critical shoot sizes for flowering and photosynthetic production. J Plant Res 114: 67-74.

Kurosawa S. 1979. Notes on chromosome numbers of Spermatophytes (2). J Jap Bot 54: 155-160.

Kurosawa S. 1981. Notes on chromosome numbers of Spermatophytes (3). J Jap Bot 56: 245-251.
Ohi T, Kajita T, Murata J. 2003. Distinct geographic structure as evidenced by chloroplast DNA haplotypes and ploidy level in Japanese Aucuba (Aucubaceae). Am J Bot 90: 1645-1652.

Osada N, Takeda H. 2003. Branch Architecture, Light Interception and Crown Development in Saplings of a Plagiotropically Branching Tropical Tree, Polyalthia jenkinsii (Annonaceae). Ann Bot 91: 55-63.

Parmesan C. 2006. Ecological and evolutionary responses to recent climate change. Annu Rev Ecol Evol S 37: 637-669.

Takasoh T, Tobe T, Aida M. 1997. Method of sectioning for microscopic observation. In: Plant cell technology series 9: Protocols for observing plant cells (Fukuda $\mathrm{H}$, Nishimura M, Nakamura K eds). Shujunsha Co. Ltd., Tokyo, pp 20-33. (in Japanese)

Terashima I, Miyazawa SI, Hanba YT. 2001. Why are sun leaves thicker than shade leaves? - Consideration based on analysis of $\mathrm{CO}_{2}$ diffusion in the leaf. J Plant Res 114: 93-105.

Wardlaw CW. 1952. Experimental and analytical studies of Pteridophytes: XVIII. The nutritional status of apex and morphogenesis. Ann Bot 16: 207-218.

Yamada T, Okuda T, Abdullah M, Awang M, Furukawa A. 2000. The leaf development process and its significance for reducing self-shading of a tropical pioneer tree species. Oecologia 125: 476-482.

Yano S, Terashima I. 2004. Developmental process of sun and shade leaves in Chenopodium album L. Plant Cell Environ 27: 781-793. 